\title{
Contrasting Quantitative Traits and Neutral Genetic Markers for Genetic Resource Assessment of Mesoamerican Cedrela Odorata
}

\author{
By C. Navarro ${ }^{\left.1,{ }^{*}\right)}$, S. Cavers ${ }^{2)}$, A. Pappinen ${ }^{3)}$, P. Tigerstedt ${ }^{3)}$, A. Lowe ${ }^{4)}$ and J. Merilä̈)
}

(Received 13 th June 2005)

\begin{abstract}
We compared within-population variability and degree of population differentiation for neutral genetic markers (RAPDS) and eight quantitative traits in Central American populations of the endangered tree, Cedrela odora$t a$. Whilst population genetic diversity for neutral markers (Shannon index) and quantitative traits (heritability, coefficient of additive genetic variation) were uncorrelated, both marker types revealed strong differentiation between populations from the Atlantic coast of Costa Rica and the rest of the species' distribution. The degree of interpopulation differentiation was higher for RAPD markers $\left(\mathrm{F}_{\mathrm{ST}}=0.67\right.$ for the sampled Mesoamerican range) than for quantitative traits $\left(\mathrm{Q}_{\mathrm{ST}}=0.30\right)$. Hence, the divergence in quantitative traits was lower than could have been achieved by genetic drift alone, suggesting that balancing selection for similar phenotypes in different populations of this species. Nevertheless, a comparison of pair-wise estimates of population differentiation in neutral genetic markers and quantitative traits revealed a strong positive correlation $(r=0.66)$ suggesting that, for $C$. odorata, neutral marker divergence could be used as a surrogate for adaptive gene divergence for conservation planning. The utility of this finding and suggested further work are discussed.
\end{abstract}

Key words: Cedrela odorata, $\mathrm{F}_{\mathrm{ST}}$, genetic differentiation, geographic variation, heritability, natural selection, quantitative traits, RAPD, $\mathrm{Q}_{\mathrm{ST}}$.

\section{Introduction}

Understanding the causes and extent of local adaptation, as well as distribution of genetic variability within and among populations are central themes in evolutionary biology and conservation genetics. Considerable efforts has been devoted to characterising population variability and differentiation for a range of species using neutral genetic markers (e.g. WARD et al., 1992; Avise, 1994; SMITH and WAYNE, 1996). However, much less work has been undertaken in this respect using quantitative traits and typically, estimates of quantitative genetic variance and heritability are limited to sin-

1) Tropical Agricultural Research and Higher Education Centre. CATIE, Turrialba, Costa Rica.

2) Centre for Ecology and Hydrology, CEH Edinburgh, Bush Estate, Penicuik, Midlothian EH26 0QB, Scotland, UK.

3) Department of Applied Biology, P.O. Box 27, FIN-00014 University of Helsinki, Finland.

4) School of Integrative Biology, University of Queensland, St. Lucia, Brisbane, Queensland 4072, Australia.

5) Ecological Genetics Research Unit, Biological and Environmental Sciences, P.O. Box 65, FIN-00014 University of Helsinki, Finland.

*) Correspondence to Carlos Navarro: Fax: +358-9-191 58751, E-mail: cnavarro@catie.ac.cr gle or few populations of a species. Studies comparing estimates of genetic variation from both neutral and quantitative markers are even less numerous (reviews in: REED and FRANKHAM, 2001; MERILÄ and CRNOKRAK, 2001; MCKAY and LATTA, 2002).

Recently, there has been increased interest in evaluating the usefulness of neutral genetic markers for drawing conclusions about quantitative trait variation (e.g. Cheverud et al., 1994; Butlin and TregenzA, 1998; WALDMANN and ANDERsson, 1998; PFRENDER et al., 2000) and differentiation (reviews in: REED and FRANKHAM, 2001; MerILÄ and CRNOKRAK, 2001; MCKAY and LATTA, 2002). This interest has been motivated by two different, albeit intimately related, desires. First, in conservation genetics, where molecular markers have been utilised at an ever-increasing rate, there is a need to establish whether variability in neutral markers reflects variability at quantitative trait loci involved in local adaptation and selection pressures. Inference based on surveys of variability in molecular markers are now routinely used as a basis for management recommendations under assumptions that maximizing marker variability will provide remnant populations with the greatest evolutionary potential, and at the same time, minimise the negative consequences of inbreeding (e.g. VRIJENHOEK, 1994; AvISE and HAMRICK, 1996; HAIG, 1998; KNAPP and RICE, 1998). Likewise, the degree of differentiation in marker genes has been suggested as a measure for guiding decisions on population conservation (e.g. MoRITZ et al., 1995) and sources for translocation or restoration projects (TEMPLETON, 1986; HAIG, 1998; KNAPP and RICE, 1998). Second, from an evolutionary perspective, the utility of neutral genetic markers for evaluating the relative importance of genetic drift and natural selection as causes of population differentiation has been a popular motive fuelling interest in comparative studies of population differentiation (MERILÄ and CRNOKRAK, 2001). This is based on the assumption that variation at neutral genetic markers will be governed primarily by forces of genetic drift and migration (HARTL and CLARK, 1989), whereas quantitative traits will also be affected by natural selection. The difference in the magnitude of standardised genetic differentiation between these two classes of marker is then used to infer the role of selection (Wright, 1951; Rogers, 1986; SPITZE, 1993; MERILÄ and CRNOKRAK, 2001).

In agreement with theoretical predictions (LANDE and BARROWCLOUGH, 1987; LYNCH, 1996), many empirical studies have found poor correspondence between variation at neutral genetic markers and quantitative traits (Cheverud et al., 1994; Butlin and Tregenza, 1998; WALDMANn and ANdersson, 1998; PFrender et al., 2000; PALO et al., 2003; but see BRISCOE et al., 1992). In addi- 
tion, a review of empirical data by REED and FRANKHAM (2001) failed to find any correlation between levels of differentiation for neutral genetic markers and quantitative traits. In contrast, a recent comparative review (MERILÄ and CRNOKRAK, 2001) of population differentiation for neutral genetic markers (as measured by $\mathrm{F}_{\mathrm{ST}}$ ) and quantitative traits (as measured by $\mathrm{Q}_{\mathrm{ST}}$ ) found that the two measures of differentiation were positively correlated for a range of species (see also: CRNOKRAK and MERILÄ, 2002), and that differentiation for quantitative traits typically exceeded that for neutral markers. However, between population comparisons within a single species are likely to be much more informative about the level of correspondence between marker types than comparisons over species. Still, most intraspecific comparisons of genetic differentiation for marker types have so far focused on average differentiation (cf. mean $\mathrm{F}_{\mathrm{ST}}$ and $\mathrm{Q}_{\mathrm{ST}}$ ), and not pair-wise estimates among populations. One possible explanation for this is that the number of populations included in each of the case studies is usually small, and hence, the power of such comparisons can be low.

Using data from 30 Mesoamerican populations of the endangered Spanish Cedar (Cedrela odorata), we estimated and compared genetic variation and differentiation in quantitative traits and neutral genetic markers to (1) identify possible locally adapted ecotypes and (2) to evaluate whether variability in marker genes is correlated with variability in genes coding quantitative traits. In particular, we evaluated the correspondence between: (1) genetic variability in neutral genetic markers (RAPD) and ecologically important quantitative traits (as reflected in additive genetic variance and heritability) across populations, and (2) degree of population differentiation in neutral genetic markers and quantita- tive traits, as measured by $\mathrm{F}_{\mathrm{ST}}$ and $\mathrm{Q}_{\mathrm{ST}}$ indices, respectively.

\section{Materials and Methods}

\section{Study species}

Spanish cedar (Cedrela odorata L.; Swietenioideae, Meliaceae) is a deciduous tree native to tropical America. It is economically the second most important species of the Meliaceae in the Neotropics, and also one of the latitudinally most widely distributed tree species on earth, with a range from $26^{\circ} \mathrm{N}$ in Mexico to $28^{\circ} \mathrm{S}$ in northern Argentina (STYLES, 1981; NAVARRO, 1999). Although Spanish Cedar is widespread, it is never very common in moist tropical American forests, and its numbers are continuing to be reduced by exploitation without successful regeneration. Individual trees are typically scattered in mixed semi-evergreen or semideciduous forests dominated by other trees. Spanish Cedar starts to reproduce at an age of 10-12 years, and the reproductive cycle is strongly influenced by local rainfall patterns, so that flowering occurs at the end of the dry season. Seeds mature during the subsequent dry season and are dispersed by wind (NAVARRO, 1999). The large climatic variation across the range means that flowering time differs among populations by up to five months. Consequently, a climatically driven phenological reproductive barrier is to be expected. In accordance with this, GILliEs et al. (1997), using RAPD markers, and CAVERs et al. (2003), using AFLP markers, found that populations of the Pacific and Caribbean coasts of Costa Rica were highly differentiated $\left(\mathrm{F}_{\mathrm{ST}}=0.452\right.$ and 0.83, respectively). Likewise, numerous provenance studies (e.g. BURLEY and LAMB, 1971; NAVARRo and VASQUEZ, 1987) suggest extensive differentiation for



Figure 1. - A map showing the location of the 30 populations of Cedrela odorata used in this study. 
Table 1. - The study populations, their coordinates with associated climatic data and seed production. $\mathrm{NDM}=$ number of dry months.

\begin{tabular}{|c|c|c|c|c|c|c|c|}
\hline Country & Population & Latitude $\left({ }^{\circ} \mathrm{N}\right) \mathrm{I}$ & Longitude $\left({ }^{\circ} \mathrm{W}\right)$ & Rainfall (mm) & Rain (start-end) & NDN & Seed collection \\
\hline México & Xpujil & 18.54 & -90.14 & $1094 *$ & Jun -Oct & 7 & March 10th \\
\hline Mexico & Nachi-Cocoon & 18.48 & -89.24 & 1094.0 & Jun -Oct & 7 & March 15 \\
\hline México & Reforma-Bacalar & 18.85 & -88.67 & 1094.0 & Jun -Oct & 7 & March 16 \\
\hline México & Tres Garantías & 18.12 & -89.14 & 1094.0 & Jun -Oct & 7 & March 17 \\
\hline México & Limones-Felipe & 19.01 & -88.00 & 1094.0 & Jun -Oct & 7 & March 20 \\
\hline México & Tulum-FCP & 19.35 & -88.01 & 1094.0 & Jun -Oct & 7 & March 22 \\
\hline México & Bacalar & 18.85 & -88.30 & 1094.0 & Jun -Oct & 7 & March \\
\hline México & Escárcega & 18.62 & -90.78 & 1094.0 & Jun -Oct & 7 & April 9 \\
\hline México & Blanca Flor & 18.92 & -88.49 & 1094.0 & Jun -Oct & 7 & March 15 \\
\hline México & Yucatán & 20.59 & -89.39 & $936^{*}$ & Jun -Sep & 8 & April 15 \\
\hline Guatemala & Los Esclavos & 14.25 & -90.28 & $2834 *$ & May-Oct & 6 & March 17 \\
\hline Guatemala & Tikal & 17.22 & -89.61 & $1366.7 * *$ & May -Nov & 5 & April 5 \\
\hline Honduras & $\mathrm{LaPaz}$ & 14.15 & -87.61 & $1976^{*}$ & May-Oct & 6 & March 26 \\
\hline Honduras & Taulabe & 14.83 & -88.10 & $2425^{*}$ & May-Oct & 6 & March 23 \\
\hline Honduras & Comayagua & 14.41 & -87.05 & $912 *$ & May-Oct & 6 & March 22 \\
\hline Honduras & Cedros & 14.66 & -87.30 & $1272 *$ & May-Oct & 6 & March 3 \\
\hline Honduras & Meambar & 14.83 & -88.10 & $2425^{*}$ & May-Oct & 6 & March 15 \\
\hline Costa Rica & Cañas & 10.32 & -85.04 & $2273.6 * * *$ & May- Nov & 5 & $15 \mathrm{Feb}$ \\
\hline Costa Rica & Upala & 10.86 & -85.02 & $2558.3 * * *$ & May-Jan & 3 & March 10 \\
\hline Costa Rica & San Carlos & 10.47 & -84.58 & $4574.1 * * *$ & Apr- Feb & 1 & March 20 \\
\hline Costa Rica & Carmona & 10.01 & -85.25 & $1779.9 * * *$ & May -Nov & 5 & Dec18 \\
\hline Costa Rica & Cóbano & 9.65 & -85.12 & $2896.8 * * *$ & May -Nov & 5 & Dec \\
\hline Costa Rica & Talamanca & 9.65 & -82.79 & $2812 * * *$ & Apr -Nov & 4 & $\mathrm{Feb}$ \\
\hline Costa Rica & Jimenez & 10.19 & -83.79 & $4465.8 * * *$ & May-Apr & 0 & Jan 9 \\
\hline Costa Rica & Hojancha & 10.07 & -85.40 & $2232.3 * * *$ & May-Nov & 5 & 15 March \\
\hline Costa Rica & Pacífico Sur & 8.62 & -82.88 & $4817.7 * * *$ & May-Apr & 0 & Feb 24 \\
\hline Costa Rica & Pérez Zeledón & 9.34 & -83.65 & $2934.5 * * *$ & Apr- Nov & 4 & Feb 26 \\
\hline Costa Rica & Liberia & 10.63 & -85.45 & $1652.7 * * *$ & May- Nov & 5 & Feb \\
\hline Costa Rica & Quepos & 9.42 & -84.16 & $3851 * * *$ & Apr- Dec & 3 & Feb \\
\hline Costa Rica & La Suiza & 9.85 & -83.61 & $2657.3 * * *$ & Apr- Feb & 1 & Feb \\
\hline Panamá & Charagre & 9.40 & -82.56 & $3319^{*}$ & Apr -Dec & 3 & Feb 11 \\
\hline Panamá & Almirante & 9.28 & -82.41 & 3319.0 & Apr -Dec & 3 & $\mathrm{Feb}$ \\
\hline Panamá & Gualaca & 8.59 & -82.23 & $2620^{*}$ & Apr -Nov & 4 & March 8 \\
\hline Panamá & Las Lajas & 8.22 & -81.86 & $2620 *$ & Apr-Nov & 4 & March 9 \\
\hline
\end{tabular}

* Data from: FAO 1985. Agroclimatological Data of Latin America and the Caribbean. FAO Plant Production and Protection Series. Roma. 19 p.

** Data from: Aguilar, M. and M. C. Aguilar. 1992. Árboles de la Biosfera Maya Petén. Universidad de San Carlos de Guatemala. $272 \mathrm{p}$.

*** Data from: Ministerio de Recursos Naturales, Energia y Minas. Instituto Metereológico Nacional. 1988. Catastro de las series de precipitaciones medidas en Costa Rica. San José, Costa Rica. 361 p.

quantitative traits between these two geographic regions.

\section{The study populations}

The 30 populations are from Mesoamerica which is defined like the area between Tehuantepec Isthmus in Mexico to the Atrato river in Panama) including the Yucatan Peninsula, a latitudinal distribution from $21^{\circ} \mathrm{N}$ in Mexico to $8^{\circ} \mathrm{N}$ in Panama (Fig. 1; Table 1). The study populations are located throughout an area of ca 41000 $\mathrm{km}^{2}$ including a wide variety of environmental conditions. For instance, mean annual rainfall among the study populations ranges from 1500 to $3500 \mathrm{~mm}$, and the number of dry months varies from 0 to 5 (Table 1). For estimates of quantitative variation, seeds from the 30 populations were raised in a randomised block, common garden glasshouse experiment at the University of Helsinki (Finland). The seedlings were raised in a mix containing sand, $40 \%$ vermiculite and $50 \%$ peat. Temperature $\left(25^{\circ} \mathrm{C}\right)$, humidity $(90 \%)$ and day-length $(12: 12$ 
Table 2. - Summary of mean genetic variability measures for different quantitative traits $\left(h^{2}=\right.$ heritability; $\mathrm{C}_{\mathrm{VA}}=$ coefficient of additive genetic variance) and RAPD markers (SDI = Shannon diversity estimate) in 14 populations of the Spanish cedar. $n_{\mathrm{Q}}=$ number families/individuals in quantitative genetic analyses. $\mathrm{n}_{M}=$ number of individuals in molecular genetic analyses.

\begin{tabular}{|c|c|c|c|c|c|c|c|c|}
\hline \multirow[b]{2}{*}{ Pop } & \multirow[b]{2}{*}{$n_{Q}$} & \multicolumn{2}{|l|}{ Mean } & \multicolumn{2}{|l|}{ Range } & \multirow[b]{2}{*}{ SDI \pm S.E. } & & \multirow[b]{2}{*}{$\mathrm{n}_{M}$} \\
\hline & & $h^{2} \pm$ S.E. & $\mathrm{CV}_{\mathrm{A}}$ & $h^{2}$ & $V_{A}$ & & & \\
\hline Charagre & $15 / 90$ & $0.488 \pm 0.63$ & 14.1 & $0.196-1.109$ & $11.0-24.1$ & $0.166 \pm 0.292$ & 11 & \\
\hline Cóbano & $7 / 40$ & $0.373 \pm 0.97$ & 14.2 & $0.069-0.716$ & $3.0-26.8$ & $0.337 \pm 0.279^{\dagger}$ & 8 & \\
\hline Escarcega & $22 / 130$ & $0.742 \pm 0.52$ & 25.6 & $0.315-1.499$ & $9.4-74.5$ & $0.042 \pm 0.115$ & 8 & \\
\hline Esclavos & $20 / 110$ & $0.731 \pm 0.30$ & 28.7 & $0.181-1.431$ & $7.0-59.1$ & $0.027 \pm 0.077$ & 19 & \\
\hline Hojancha & $9 / 54$ & $0.792 \pm 0.67$ & 18.8 & $0.475-1.428$ & $13.4-35.7$ & $0.313 \pm 0.290^{\dagger}$ & 6 & \\
\hline Jimenez & $5 / 25$ & $0.578 \pm 0.98$ & 17.1 & $0.349-1.878$ & $11.2-58.8$ & $0.240 \pm 0.292^{\dagger}$ & 5 & \\
\hline La Paz & $13 / 61$ & $0.153 \pm 0.22$ & 6.3 & $0.056-0.460$ & $10.8-15.3$ & $0.011 \pm 0.038$ & 15 & \\
\hline Cañas & $6 / 30$ & $1.386 \pm 0.81$ & 68.6 & $0.694-1.994$ & $15.7-148.6$ & $0.369 \pm 0.276^{\dagger}$ & 6 & \\
\hline Pacífico Sur. & $19 / 114$ & $0.867 \pm 0.14$ & 33.8 & $0.509-1.524$ & $13.1-84.4$ & $0.175 \pm 0.263$ & 12 & \\
\hline San Carlos & $15 / 85$ & $0.507 \pm 0.22$ & 19.6 & $0.060-1.299$ & $8.5-38.5$ & $0.361 \pm 0.281^{\dagger}$ & 14 & \\
\hline Talamanca & $4 / 24$ & $0.266 \pm 0.72$ & 10.6 & $0.177-0.277$ & $8.8-58.0$ & $0.296 \pm 0.307^{\dagger}$ & 4 & \\
\hline Upala & $19 / 111$ & $1.066 \pm 0.36$ & 52.7 & $0.602-1.479$ & $15.8-108.9$ & $0.277 \pm 0.307^{\dagger}$ & 7 & \\
\hline Xpujil & $22 / 132$ & $0.765 \pm 0.34$ & 22.4 & $0.043-1.365$ & $2.9-60.6$ & $0.071 \pm 0.196$ & 13 & \\
\hline Yucatan & $13 / 74$ & $0.820 \pm 0.59$ & 28.5 & $0.330-1.361$ & $8.3-46.8$ & $0.107 \pm 0.225$ & 13 & \\
\hline
\end{tabular}

${ }^{\dagger}$ Estimates based on data from GiLliEs et al., 1997.

dark/light) were kept constant, and the seedlings were watered daily. For characterisation of molecular genetic variability using RAPD markers, we were constrained to genotype material from only seven of these populations as indicated in Table 2. However, data for an additional seven populations (Table 2) was obtained from GILLIES et al. (1997).

\section{Neutral genetic marker analyses}

Estimates of levels of neutral genetic population diversity and differentiation were made using RAPD markers. DNA extraction was performed on seeds germinated from 400 single mother trees using a modified CTAB method (GILliEs et al., 1997). PCR amplification of the DNA was performed in $25 \mu \mathrm{l}$ volume using 10 pairs of Operon Technologies Ltd primers (OPC1-10) using a MJR thermal cycler. Program conditions were: 45 cycles of 1 minute at $94^{\circ} \mathrm{C}, 1$ minute at $36^{\circ} \mathrm{C}$, and 2 minutes at $72{ }^{\circ} \mathrm{C}$; and a final cycle of 7 minutes at $72^{\circ} \mathrm{C}$. Each PCR reaction included: 1/10 buffer, $2 \mathrm{mM}$ dNTPs, 1 unit of Dynazyme Taq DNA polymerase (Finnzymes), $0.4 \mu \mathrm{m}$ primers and distilled water to a volume of $25 \mu \mathrm{l}$. The products were visualised under UV transillumination (in 0.1\% TBE buffer containing a few drops of ethidium bromide) after separation in $1.8 \%$ agarose gels (Sigma). Presence/absence of each scorable RAPD fragment was recorded in a binary data matrix and POPGENE v1.2 (YEH, 1997) was used to calculate the frequency of polymorphic bands in each population. On average 13 (range: 8-19) individuals (one per family) were genotyped from each of the populations listed in Table 2.

Since interpretation of RAPD patterns does not follow segregation rules of standard co-dominant markers, Shannon's Diversity Index (SDI; as calculated by the software package POPGENE v1.31; YEH, 1998) was used as a measure of intra-population genetic diversity. It is well suited to the analysis of RAPD data as it is relatively insensitive to the bias produced by failures to detect heterozygous individuals (DAwson et al., 1995). Since the indices of variability used for the analysis of RAPD markers (OPC1-17) in the study of GILLIES et al. (1997) were different from ours, SDIs were recalculated for their data using the data given in their Table 2. Since the primers used in our study and that of GiLLIES et al. (1997) were not the same, the calculated measures may still not be comparable between the two data sets. In fact, the mean $( \pm$ S.E.) SDI is significantly higher $(0.31 \pm 0.17)$ for the populations genotyped by GILLIES $e t$ al. (1997) than for populations genotyped in this study $(0.09 \pm 0.25 ;$ MANN-Whitney, $z=3.13, P=0.0017)$, despite the mean number of individuals genotyped per population being lower in the former study ( $x=7.4$ and 13, respectively; MANN-Whitney, $z=2.43, P=0.015$ ). Whether the difference in RAPD variability is due to differences in primer specificity, or the geographic range of samples (all populations typed by GILLIEs et al., 1997, originate from Costa Rica), cannot be ascertained. However, CAVERS et al. (2003) also found low levels of variability for AFLP markers on a similar range of samples 
as those used by GiLLIES et al. (1997). Hence, to be cautious, we performed separate analyses for the two data sets (henceforth: data-set 1: populations genotyped in this study; data-set 2: populations genotyped by GiLLIES et al., 1997), in addition to pooled analyses.

The degree of population differentiation for RAPD markers, corresponding to $\mathrm{F}_{\mathrm{ST}}$ and its standard error, was obtained from partitioning the variability in the data into within $\left(v_{w}\right)$ and between $\left(v_{b}\right)$ population components of genetic variation (WRIGHT, 1951) using the formula:

$$
F_{S T}=\frac{v_{b}}{v_{b}+v_{w}}
$$

$\mathrm{F}_{\mathrm{ST}}$ was calculated separately for the two data sets and on pooled data. Standard errors were obtained using a Bayesian approach (Holsinger and LewIS, 2002; HOLSINGER et al., 2002).

\section{Quantitative genetic analyses}

Estimates of population genetic variability and differentiation were obtained for eight quantitative traits. Depending on the population, 4-22 (average $=13.5$, see Table 2) seeds were sampled from each open pollinated mother tree. One seedling per family was sown in each of the six blocks. Due to mortality (1.2\%) during the experiment, on average 5.6 individuals per family (1080 in total) were measured for the traits described below. The wide range of variation in the number of families used per population is due to the scarce and endangered nature of $C$. odorata, and the number of families per population reflects local population size (Table 2).

The response variables measured on seedlings at an age of 62 days included: (1) Height ( $\mathrm{H}$; in $\mathrm{mm}),(2)$ leaflet length (LL; in $\mathrm{mm}$ ), (3) width of the third leaflet from the tip of the leaf LW), and (4) leaflet shape index as obtained by dividing leaf length by leaflet width (LL/LW). In addition, 252 days after sowing, eight additional measurements were obtained. These were: (5) height ( $\mathrm{H} 2$ in $\mathrm{mm}),(6)$ internodal distance (ID; the length of the stem from the tip to the fourth branch in $\mathrm{cm}),(7)$ trunk diameter ( $\mathrm{D}$; in $\mathrm{cm}$ at $2 \mathrm{~cm}$ height from the soil, (8) the number of leaflets per leaf (NL). The mean values ( \pm S.E.) of these traits are given in Table 3 .

To estimate population specific heritabilities and coefficients of additive genetic variance $\left(\mathrm{CV}_{\mathrm{A}}\right.$; Houle, 1992), data for each population and trait was subjected to variance component estimation using the REML algorithm of PROC VARCOMP in SAS. For these analyses, models included the term family (random effect). Because open pollinated trees were used, we assumed that the members of the same family were half-sibs, i.e. that the term family estimates $1 / 4 \mathrm{~V}_{\mathrm{A}}$. This assumption may lead to overestimation of heritability as the seeds from single trees may also contain full sibs or selfed offspring. Likewise, from the point of view of $\mathrm{Q}_{\mathrm{ST}}$ estimates (see below), this assumption will render our estimates of interpopulation differentiation conservative.

Narrow sense heritabilities $\left(h^{2}\right)$ were obtained as $h^{2}=$ $4 \times \sigma_{\mathrm{F}}^{2}, / \sigma_{\mathrm{P}}^{2}$, where $\sigma_{\mathrm{F}}^{2}$ is the variance component due to family and $\sigma^{2}$ is the total phenotypic variance of the trait (i.e. $\sigma_{\mathrm{F}}^{2}+\sigma_{\mathrm{E}}^{2}$ ), where $\sigma_{\mathrm{E}}^{2}$ is the residual component of variance. The standard errors for heritability were calculated according to DiETERs et al. (1996). $\mathrm{CV}_{\mathrm{A}} \mathrm{s}$ were calculated according to Houle (1992) as $\mathrm{CV}_{\mathrm{A}}=100$ $\sqrt{ } \mathrm{V}_{\mathrm{A}} / x$, where $\mathrm{V}_{\mathrm{A}}$ is the additive genetic variance, and $x$ is the mean trait value in the sample used to estimate the $\mathrm{V}_{\mathrm{A}}$.

To obtain a standardised estimate of among population differentiation comparable to $\mathrm{F}_{\mathrm{ST}}$ for molecular markers, we estimated $\mathrm{Q}_{\mathrm{ST}}$ values as:

$$
Q_{S T}=\frac{\sigma_{G B}^{2}}{2 \sigma_{G W}^{2}+\sigma_{G B}^{2}}
$$

where $\sigma_{\text {GB }}^{2}$ is the among population component of genetic variance, and $\sigma^{2}{ }_{\mathrm{GW}}$ is the within population genetic component of variance (WRIGHT, 1951; MERILÄ and CRNOKRAK, 2001). The among population component of variance for each trait was estimated as the added variance component from a mixed linear model performed using data from all populations (or in the case of pair-

Table 3. - Least square means and standard errors for quantitative traits in Cedrela odorata greenhouse study. See methods for trait abbreviations. $n=$ number of families/individuals.

\begin{tabular}{|c|c|c|c|c|c|c|c|c|c|}
\hline Population & $\mathrm{H}$ & LW & LL & LL/LW & $\mathrm{H} 2$ & D & ID & $\mathrm{NL}$ & $n$ \\
\hline Charagre & $99.7 \pm 1.5$ & $11.2 \pm 0.2$ & $32.0 \pm 0.3$ & $2.93 \pm 0.05$ & $8.3 \pm 0.5$ & $0.30 \pm 0.01$ & $5.7 \pm 1.9$ & $4.3 \pm 1.7$ & $15 / 90$ \\
\hline Cobano & $99.2 \pm 3.3$ & $12.8 \pm 0.6$ & $31.8 \pm 1.3$ & $2.56 \pm 0.09$ & $60.9 \pm 5.3$ & $0.92 \pm 0.08$ & $36.1 \pm 1.7$ & $15.6 \pm 0.7$ & $7 / 40$ \\
\hline Escarcega & $133.8 \pm 1.7$ & $15.2 \pm 0.2$ & $36.6 \pm 0.4$ & $2.46 \pm 0.03$ & $64.3 \pm 3.9$ & $0.80 \pm 0.04$ & $37.7 \pm 1.8$ & $17.1 \pm 0.7$ & $22 / 130$ \\
\hline Esclavos & $126.8 \pm 2.7$ & $15.3 \pm 0.3$ & $37.2 \pm 0.6$ & $2.48 \pm 0.04$ & $65.9 \pm 3.3$ & $0.80 \pm 0.03$ & $36.9 \pm 1.5$ & $17.0 \pm 0.6$ & $20 / 110$ \\
\hline Hojancha & $123.0 \pm 2.3$ & $16.6 \pm 0.3$ & $43.0 \pm 0.7$ & $2.63 \pm 0.05$ & $64.1 \pm 2.7$ & $0.89 \pm 0.03$ & $42.5 \pm 1.5$ & $18.2 \pm 1.1$ & $9 / 54$ \\
\hline Jiménez & $86.5 \pm 5.0$ & $9.4 \pm 0.4$ & $27.8 \pm 1.1$ & $3.04 \pm 0.13$ & $10.1 \pm 1.0$ & $0.31 \pm 0.02$ & $8.1 \pm 2.6$ & $5.1 \pm 2.0$ & $5 / 25$ \\
\hline Cañas & $97.5 \pm 2.9$ & $12.7 \pm 0.4$ & $32.4 \pm 1.1$ & $2.63 \pm 0.13$ & $50.9 \pm 0.8$ & $0.68 \pm 0.02$ & $24.4 \pm 1.7$ & $14.5 \pm 1.2$ & $6 / 30$ \\
\hline La Paz & $120.4 \pm 2.9$ & $14.5 \pm 0.4$ & $38.4 \pm 0.8$ & $2.71 \pm 0.07$ & $70.3 \pm 7.3$ & $0.89 \pm 0.08$ & $38.1 \pm 2.9$ & $16.2 \pm 0.8$ & $13 / 61$ \\
\hline Pacífico Sur & $116.6 \pm 2.6$ & $11.7 \pm 0.2$ & $32.2 \pm 0.3$ & $2.82 \pm 0.03$ & $12.9 \pm 0.7$ & $0.32 \pm 0.02$ & $8.1 \pm 2.2$ & $3.2 \pm 1.4$ & $19 / 114$ \\
\hline San Carlos & $77.0 \pm 1.5$ & $7.6 \pm 0.2$ & $24.2 \pm 0.4$ & $3.25 \pm 0.07$ & $9.0 \pm 0.9$ & $0.23 \pm 0.01$ & $8.9 \pm 5.9$ & $7.1 \pm 1.9$ & $15 / 85$ \\
\hline Talamanca & $58.8 \pm 3.3$ & $8.7 \pm 0.5$ & $28.1 \pm 1.5$ & $3.41 \pm 0.13$ & $8.4 \pm 0.5$ & $0.25 \pm 0.02$ & $7.3 \pm 5.5$ & $7.3 \pm 2.8$ & $4 / 24$ \\
\hline Upala & $111.8 \pm 1.9$ & $11.6 \pm 0.2$ & $34.2 \pm 0.4$ & $3.11 \pm 0.07$ & $17.8 \pm 13$ & $0.40 \pm 0.02$ & $14.6 \pm 1.7$ & $9.4 \pm 4.6$ & $19 / 111$ \\
\hline Xpujil & $119.0 \pm 1.7$ & $14.7 \pm 0.2$ & $36.9 \pm 0.4$ & $2.55 \pm 0.03$ & $73.7 \pm 4.1$ & $1.04 \pm 0.06$ & $39.9 \pm 2.1$ & $19.3 \pm 1.0$ & $22 / 132$ \\
\hline Yucatán & $124.4 \pm 1.9$ & $14.6 \pm 0.2$ & $34.0 \pm 0.5$ & $2.36 \pm 0.03$ & $52.7 \pm 5.4$ & $0.80 \pm 0.04$ & $35.0 \pm 2.8$ & $15.8 \pm 0.6$ & $13 / 74$ \\
\hline
\end{tabular}

Trait mean \pm S.E 
wise estimates, for the two populations in question). The within population component was obtained as explained above. To evaluate the implications of assuming members of a given family were half- rather than full-sibs (or

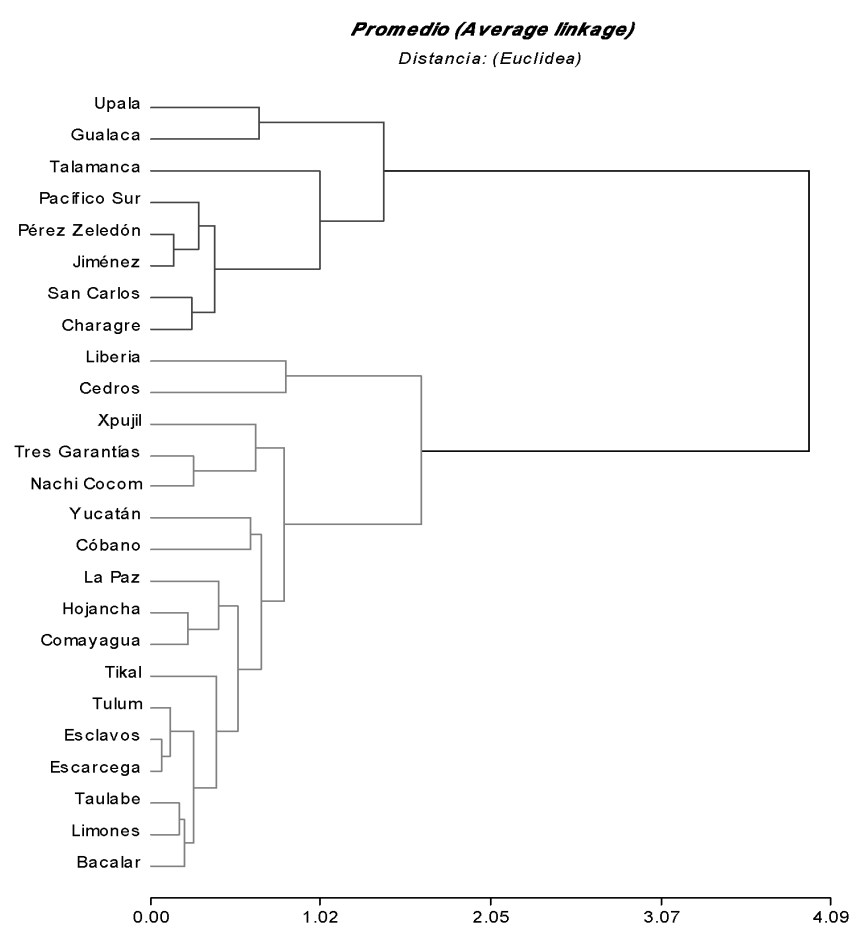

Figure 2. - Cluster analyses of quantitative traits in a greenhouse in Finland. Note that the clusters correspond to mesic (Almirante to Upala) and dry (Bacalar to Yucatan) environment populations. The morphological distances are based on Euclidean distances and the genetic distances on Nei's (1987) genetic distances. a mixture), we also estimated $\mathrm{Q}_{\mathrm{ST}}$ values under assumptions that all the offspring in a given family were fullsibs.

Cluster analyses were used to examine similarities between populations for all quantitative characters using Euclidean distances and the software (Infostat, 2005).

\section{Comparison of neutral and quantitative genetic variability}

To investigate correspondence between neutral and quantitative genetic variability across the populations, we calculated pair-wise Spearman product moment correlations between Shannon's Diversity Index for RAPD markers and heritability estimates for (1) each of the quantitative traits separately, and (2) for the mean heritability estimates for different traits. Since the different traits vary greatly both in terms of size and dimensionality, we also performed analyses using standardised measures of additive genetic variance using coefficients of additive genetic variability $\left(\mathrm{CV}_{\mathrm{A}}\right.$; Houle, 1992). Because the genetic variability measures based on RAPD markers may not be comparable between the two RAPD data sets, we performed tests for data involving (i) only populations scored for this study, (ii) only populations scored by GILLIES et al. (1997), and (iii) on combined data.

To investigate correspondence between levels of neutral and quantitative genetic differentiation, we first compared the overall estimates of $\mathrm{F}_{\mathrm{ST}}$ and $\mathrm{Q}_{\mathrm{ST}}$ for the two data sets using two-sample $t$-tests. For these tests, each locus and trait were considered as independent observations. To see whether pairwise population estimates of $\mathrm{F}_{\mathrm{ST}}$ and $\mathrm{Q}_{\mathrm{ST}}$ are correlated, we performed a

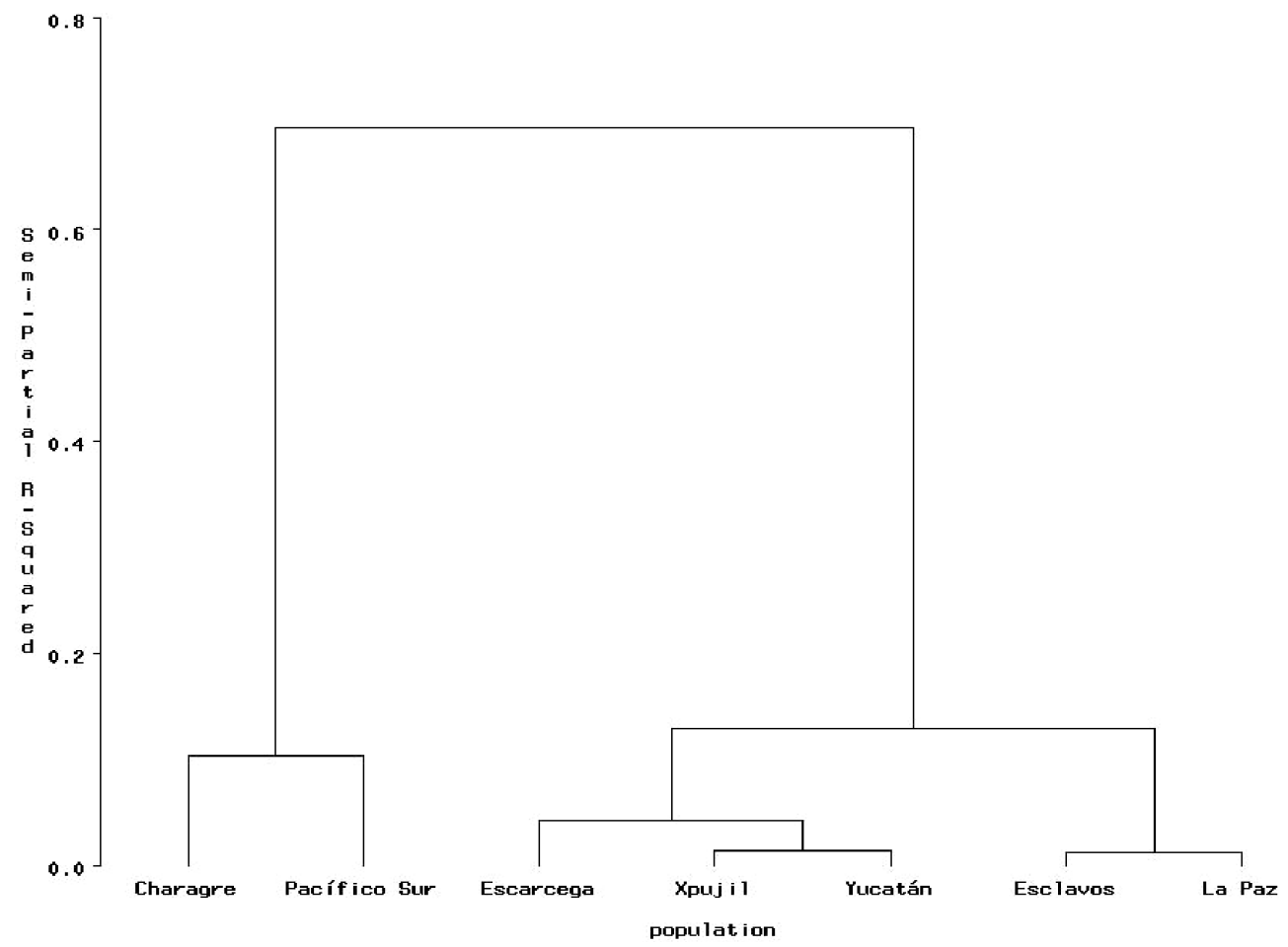

Figure 3. - Cluster analyses of RAPD data for the seven C. odorata populations in the sub-set 1 (see methods). 
Table 4. - Nested analyses of variance of quantitative traits and RAPD markers, together with associated $\mathrm{Q}_{\mathrm{ST}}$ and $\mathrm{F}_{\mathrm{ST}}$ estimates for different subdivisions of data. $\mathrm{Q}_{\mathrm{ST}}$ estimates are given under assumption of half-sib (HS) and fullsib (FS) structure of the data. $\mathrm{POP}=$ population, $\mathrm{FAM}=$ family (nested within population), ERR = error variance components, respectively.

\begin{tabular}{|c|c|c|c|c|c|}
\hline Trait & POP & FAM & ERR & $Q_{S T(H S)} \pm S E$ & $\mathrm{Q}_{\mathrm{ST}(\mathrm{FS})} \pm \mathrm{SE}$ \\
\hline \multicolumn{6}{|c|}{ All populations } \\
\hline $\begin{array}{l}\text { H62 } \\
\text { LW62 } \\
\text { LL62 } \\
\text { LL/ML62 } \\
\text { HC252 } \\
\text { D252 } \\
\text { ID252 } \\
\text { NL252 }\end{array}$ & $\begin{array}{r}410.24^{* *} \\
7.182^{\star *} \\
22.549^{\star *} \\
0.090^{\star *} \\
711.66^{\star *} \\
0.08^{\star *} \\
246.14^{\star *} \\
44.46^{\star *}\end{array}$ & $\begin{array}{r}130.06^{\star \star *} \\
1.95^{\star \star *} \\
5.56^{\star \star *} \\
0.05^{\star \star *} \\
205.29^{\star * *} \\
0.02^{\star \star \star} \\
26.47^{\star *} \\
6.48^{* \star}\end{array}$ & $\begin{array}{r}429.63 \\
5.88 \\
26.37 \\
0.23 \\
319.62 \\
0.05 \\
115.13 \\
32.55\end{array}$ & $\begin{array}{l}0.283 \pm 0.014 \\
0.315 \pm 0.017 \\
0.336 \pm 0.019 \\
0.172 \pm 0.006 \\
0.302 \pm 0.015 \\
0.324 \pm 0.014 \\
0.538 \pm 0.048 \\
0.462 \pm 0.037\end{array}$ & $\begin{array}{l}0.441 \pm 0.034 \\
0.479 \pm 0.039 \\
0.503 \pm 0.043 \\
0.293 \pm 0.017 \\
0.464 \pm 0.037 \\
0.489 \pm 0.033 \\
0.699 \pm 0.081 \\
0.632 \pm 0.069\end{array}$ \\
\hline Mean $Q_{S T}$ & & & & $0.341 \pm 0.021$ & $0.500 \pm 0.044$ \\
\hline \multicolumn{6}{|l|}{ Subset 1} \\
\hline $\begin{array}{l}\text { H62 } \\
\text { LW62 } \\
\text { LL62 } \\
\text { LL/WL62 } \\
\text { HC252 } \\
\text { D252 } \\
\text { ID252 } \\
\text { NL252 }\end{array}$ & $\begin{array}{l}100.06^{*} \\
2.71^{*} \\
5.78^{\star} \\
0.04^{*} \\
737.04^{*} \\
0.07^{*} \\
226.69^{*} \\
43.24^{*}\end{array}$ & $\begin{array}{l}119.40^{\star * *} \\
1.83^{\star * *} \\
5.39^{\star \star \star *} \\
0.02^{\star * *} \\
219.01^{* * *} \\
0.02^{\star \star} \\
15.25 \\
1.27\end{array}$ & $\begin{array}{l}485.50 \\
5.962 \\
24.75 \\
0.158 \\
463.720 \\
0.060 \\
141.230 \\
33.837\end{array}$ & $\begin{array}{l}0.230 \pm 0.004 \\
0.260 \pm 0.009 \\
0.260 \pm 0.006 \\
0.150 \pm 0.000 \\
0.230 \pm 0.013 \\
0.270 \pm 0.008 \\
0.430 \pm 0.014 \\
0.460 \pm 0.009\end{array}$ & $\begin{array}{l}0.173 \pm 0.012 \\
0.270 \pm 0.027 \\
0.211 \pm 0.018 \\
0.282 \pm 0.001 \\
0.457 \pm 0.045 \\
0.490 \pm 0.030 \\
0.788 \pm 0.053 \\
0.895 \pm 0.035\end{array}$ \\
\hline $\begin{array}{l}\text { Mean } Q_{S T} \\
F_{S T}\end{array}$ & & & & $\begin{array}{l}0.286 \pm 0.008 \\
0.667 \pm 0.064\end{array}$ & $0.446 \pm 0.028$ \\
\hline \multicolumn{6}{|l|}{ Subset 2} \\
\hline $\begin{array}{l}\text { H62 } \\
\text { LW62 } \\
\text { LL62 } \\
\text { LL/WL62 } \\
\text { HC252 } \\
\text { D252 } \\
\text { ID252 } \\
\text { NL252 }\end{array}$ & $\begin{array}{l}422.09^{*} \\
9.34^{*} \\
36.37^{*} \\
0.08^{*} \\
635.71^{*} \\
0.08^{*} \\
252.55^{\star} \\
43.99\end{array}$ & $\begin{array}{l}152.33^{* * *} \\
2.18^{\star * *} \\
5.89^{\star *} \\
0.12^{\star * \star} \\
162.38^{\star \star \star} \\
0.02^{\star * *} \\
43.95^{\star *} \\
15.60^{\star \star}\end{array}$ & $\begin{array}{l}321.080 \\
5.729 \\
29.521 \\
0.376 \\
88.442 \\
0.024 \\
72.621 \\
30.453\end{array}$ & $\begin{array}{l}0.257 \pm 0.026 \\
0.348 \pm 0.044 \\
0.436 \pm 0.063 \\
0.083 \pm 0.004 \\
0.329 \pm 0.039 \\
0.320 \pm 0.035 \\
0.418 \pm 0.063 \\
0.261 \pm 0.028\end{array}$ & $\begin{array}{l}0.409 \pm 0.065 \\
0.517 \pm 0.097 \\
0.607 \pm 0.123 \\
0.153 \pm 0.013 \\
0.495 \pm 0.089 \\
0.485 \pm 0.080 \\
0.590 \pm 0.126 \\
0.413 \pm 0.069\end{array}$ \\
\hline $\begin{array}{l}\text { Mean } Q_{S T} \\
F_{S T}\end{array}$ & & & & $\begin{array}{l}0.306 \pm 0.038 \\
0.325 \pm 0.093\end{array}$ & $0.459 \pm 0.083$ \\
\hline
\end{tabular}

$* \mathrm{P}<0.05, * * \mathrm{P}<0.01, * * * \mathrm{P}<0.001$.

Mantel's test (5000 permutations; Excel add-in 'PopTools' ver. 2.3; www.cse.csiro.au/CDG/poptools). Note that only 42 out of 66 possible pair-wise comparisons among 14 populations were possible because of the different marker systems used for the two RAPD data sets. Pair-wise comparisons were again performed separately for the two data sets (21 pair-wise comparisons for each subset).

\section{Results}

\section{Descriptive patterns differentiation}

Cluster analyses of quantitative traits revealed a strong differentiation between Atlantic populations of Costa Rica/Panama and Mexico/Honduras (Fig. 2). This same pattern was also evident in RAPD data (Fig. 3), showing that differentiation between populations from the Atlantic coast of Costa Rica and the rest of the species' distribution can be seen both in marker and quantitative trait data. Approximately $68 \%$ of the variation in quantitative traits was partitioned among popu- lations, with populations from northern Central America and Mexico being larger in all traits than populations from the Atlantic coast of Costa Rica (Table 4).

\section{Comparison of genetic variability}

Mean heritabilities and $\mathrm{CV}_{\mathrm{A}} \mathrm{s}$, as well as their ranges are given in Table 2. Fifty-eight out of the 112 heritability estimates were significant, and average per population estimates of trait heritability ranged from 0.15 to 1.38, with $\mathrm{CV}_{\mathrm{A}} \mathrm{s}$ between 6 and 81 (Table 2). The average Shannon's diversity index for the RAPD data ranged from 0.01 to 0.17 (Table 2). There was no correlation between levels of genetic variability for neutral genetic markers and average heritability in combined $\left(r_{\mathrm{s}}=0.03\right.$, $n=14, P=0.50$ ), or in the separate datasets (Data-set 1: $r_{\mathrm{s}}=0.14, n=7, P=0.41$; Data-set 2: $r_{\mathrm{s}}=0.04, n=7$, $P=0.65$ ). The same was true for CVAs (Combined data: $r_{\mathrm{s}}=0.07 n=14, P=0.35$; Data-set 1: $r_{\mathrm{s}}=0.08, n=7$, $P=0.54$; Data-set $\left.2: r_{\mathrm{s}} 0.08, n=7, P=0.53\right)$. When tested on a per trait basis for different groupings of data, none of the 24 (i.e. 8 traits $\times 3$ groupings) possible corre- 
lations were significant for heritability or CVA based analyses, respectively.

\section{Comparison of genetic differentiation}

$\mathrm{F}_{\mathrm{ST}}$ estimates of RAPD markers revealed a high degree of population subdivision for both data sets (Data-set 1: $\mathrm{F}_{\mathrm{ST}}=0.670 \pm 0.060 ; P<0.001$; Data-set 2: $\left.\mathrm{F}_{\mathrm{ST}}=0.329 \pm 0.002 ; P<0.001\right)$. The results were also similar when NEI's (NEI, 1987) $\mathrm{G}_{\mathrm{ST}}$ estimator of $\mathrm{F}_{\mathrm{ST}}$ is used (Data-set 1: $\mathrm{G}_{\mathrm{ST}}=0.60$; Data-set 2: $\mathrm{G}_{\mathrm{ST}}=0.36$ ). The lower degree of differentiation for Data-set 2 compared to 1 is not surprising given the more restricted geographic coverage of the former (average [ \pm S.E.] geographic distance between populations: Data-set $1=$ $818.3 \pm 107.4 \mathrm{~km}$, Data-set $2=142.2 \pm 17.34 \mathrm{~km}$; MannWhitney, $z=4.67, n=42, P<0.001)$.

In contrast, the degree of quantitative trait differentiation, albeit substantial, was much lower than that observed for RAPD markers, under the assumption of half-sib family structure (Table 4). Average $\mathrm{Q}_{\mathrm{ST}}$ across all populations was 0.30 (S.E. $=0.02)$, ranging from 0.17 to 0.53 for individual traits (Table 4). $\mathrm{Q}_{\mathrm{ST}}$ values for Data-set 1 was 0.29 (S.E. $=0.01$ ) and for Data-set 2 was 0.31 (S.E. $=0.04)$ : these are significantly lower than (Data-set 1) or similar to (Data-set 2) the corresponding $\mathrm{F}_{\mathrm{ST}}$ estimates for neutral genetic markers ( $t$-tests; Dataset 1: $t_{21}=19.34, \mathrm{P}<0.001 ;$ Data-set $2: t_{16}=0.63$, $P=0.53$ ). If full-sib family structure is assumed (Table $4), \mathrm{Q}_{\mathrm{ST}}$ estimates are lower than $\mathrm{F}_{\mathrm{ST}}$ estimates for Dataset $1\left(t_{21}=6.66, P<0.0001\right)$, but statistically indistinguishable for Data set $2\left(t_{16}=1.61, P=0.15\right)$.

Although the degree of among population differentiation was much higher (or approximately equal if full-sib family structure is assumed) for RAPD markers compared to quantitative traits, pair-wise $\mathrm{Q}_{\mathrm{ST}}$ estimates were strongly positively correlated with $\mathrm{F}_{\mathrm{ST}}$ estimates, for both data sets (Mantel's tests; Data-set 1: $r=0.69$, $P<0.001$; Data-set 2: $r=0.55, P=0.020$; Fig. $4 a$ and $b$ ). This is also true also for the pooled data sets (Mantel's test: $r=0.93, P<0.001$; Fig. $4 c$ ).

\section{Discussion}

The most salient findings of this study were that while the degree of differentiation for quantitative traits was lower than (or at best, similar to) that observed for neutral genetic markers, these two measures were strongly positively correlated in pairwise population comparisons. However, the levels of intra-population diversity for neutral genetic markers and quantitative traits were uncorrelated across populations. In what follows, we will discuss each of these findings, as well as their general implications, in turn. We end up with discussing the specific implications of the results for management and conservation of $C$. odorata populations.

\section{Selection, drift or stabilising selection?}

A common pattern in studies which have compared $\mathrm{F}_{\mathrm{ST}}$ and $\mathrm{Q}_{\mathrm{ST}}$ values for neutral genetic markers and quantitative traits, respectively, is that the degree of differentiation for the latter typically exceeds the former,
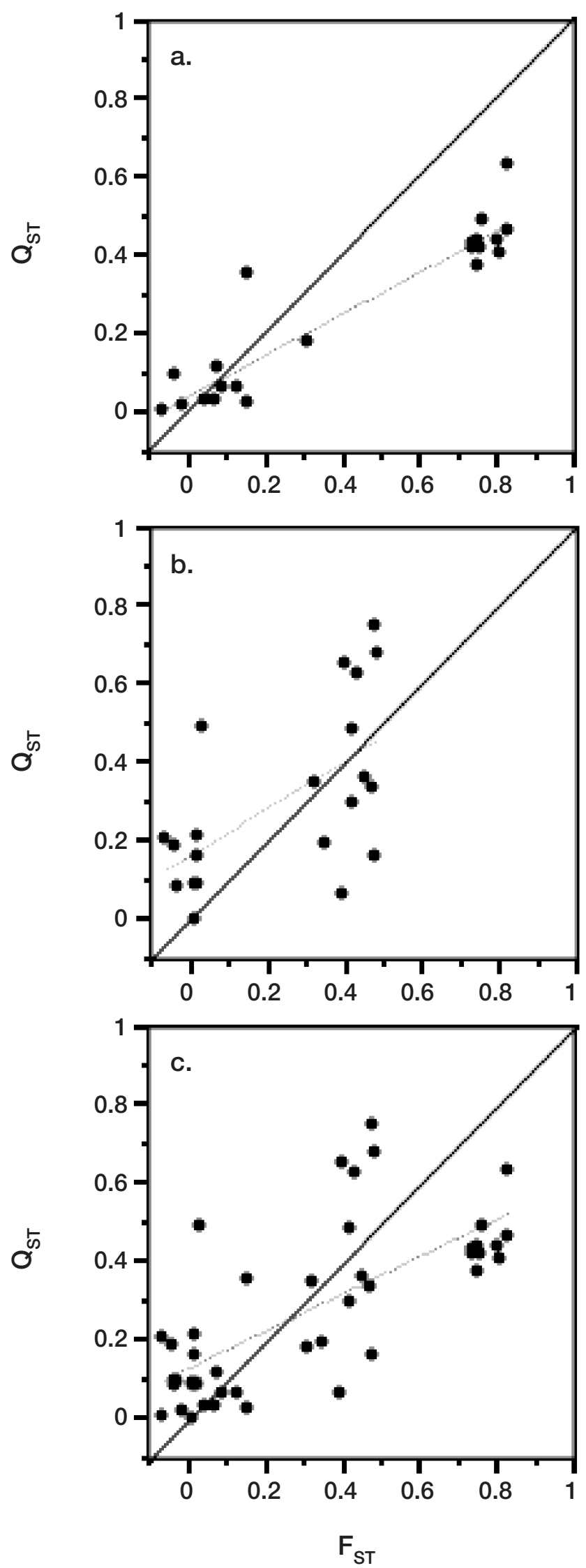

Figure 4. - Comparison of pair-wise $\mathrm{Q}_{\mathrm{ST}}$ and $\mathrm{F}_{\mathrm{ST}}$ estimates across the study populations for (a) Sub-set 1, (b) sub-set 2 and (c) and combined data. The solid line marks a 1:1 relationship for the correspondence between $\mathrm{Q}_{\mathrm{ST}}$ and $\mathrm{F}_{\mathrm{ST}}$ estimates, and the dotted lines are least square regression lines given for the ease of interpretation. See text for statistical tests. 
i.e. $\mathrm{Q}_{\mathrm{ST}}>\mathrm{F}_{\mathrm{ST}}$ (reviewed in: MERILÄ and CRNOKRAK, 2001; MCKAY and LATTA, 2002). This suggests that quantitative traits are typically under directional selection, and different populations exhibit different mean trait values, because under an assumption of neutrality, $\mathrm{F}_{\mathrm{ST}}$ and $\mathrm{Q}_{\mathrm{ST}}$ values are expected to be approximately equal (e.g. WHITLOCK, 1999). On the other hand, if $\mathrm{Q}_{\mathrm{ST}}<\mathrm{F}_{\mathrm{ST}}$, this suggests that quantitative trait divergence among populations is less than that expected due to a balance between genetic drift and migration. This is what we observed in the case of Spanish Cedar, suggesting that quantitative traits across populations are under some form of stabilising selection favouring similar phenotypes in different areas. This notwithstanding that the populations were shown to be strongly differentiated for mean values of all traits, and that the magnitude of differentiation in quantitative traits (mean $\left.\mathrm{Q}_{\mathrm{ST}}=0.34\right)$ was comparable to that observed in other studies (mean $\mathrm{Q}_{\mathrm{ST}}$ of 18 published studies = 0.37; MERILÄ and CRNOKRAK, 2001). Isolation in small populations is a likely explanation for high degree of differentiation at neutral loci, but in the case of quantitative traits, differentiation can be counteracted by selection. Another explanation for the observation that $\mathrm{Q}_{\mathrm{ST}}<\mathrm{F}_{\mathrm{ST}}$ is that we underestimated the degree of differentiation in quantitative traits. There are two reasons why this could be so. First, our estimates of additive genetic variance are likely to include maternal and dominance effects, which will lead to downward biased estimates of $\mathrm{Q}_{\mathrm{ST}}$ (see Equation 2). Secondly, since we used open pollinated mother trees, it is not entirely certain whether the offspring were full- or half-sibs or even selfed. In the absence of more detailed information, it is perhaps safest to assume that the offspring in a given family were half- rather than full-sibs (SQUILLACE, 1974). Nevertheless, even if we assume a full sib family relationship, the mean $\mathrm{Q}_{\mathrm{ST}}$ is 0.44 and 0.45 for the two data sets. Hence, even if the degree of differentiation might actually be in the range explained by genetic drift alone, it is fairly clear that the quantitative trait differentiation does not exceed that expected due to drift. Similar results have been recently obtained from few other studies (e.g. Petit et al., 2001; EDMANS and HARRISON, 2002; LEE and Frost, 2002).

\section{Marker vs. quantitative trait divergence across different populations}

In a review of earlier studies, MERILÄ and CRNOKRAK (2001) showed that the degree of differentiation among populations for quantitative traits was predictable from knowledge of the degree of differentiation at neutral genetic markers. Although MERILÄ and CRNOKRAK (2001) indicated that neutral genetic markers can be used as surrogate estimates for adaptive differentiation among populations, this may be a premature conclusion as the data on which this result is based comprised studies where both $\mathrm{F}_{\mathrm{ST}}$ and $\mathrm{Q}_{\mathrm{ST}}$ values ranged from zero to unity. Such variation is seldom observed in intraspecific studies, and in fact, only few studies to date has attempted to test for this relationship with intraspecific data (LONG and SingH, 1995; Morgan et al., 2001; Steiger et al., 2002; GonZALES-MARTINEZ et al., 2002; PALO et al., 2003). In our study, we found a strong posi- tive correlation between pair-wise $\mathrm{F}_{\mathrm{ST}}$ and $\mathrm{Q}_{\mathrm{ST}}$ estimates, corroborating the interspecific-level comparisons of LYNCH et al. (1999) and MERILÄ and CRNOKRAK (2001). This is noteworthy, as it suggests that knowledge of the degree of population differentiation for neutral genetic markers is informative about the degree of genetic differentiation for ecologically important traits in $C$. odorata. Similar positive correlation has been earlier observed also in some other intraspecific studies (e.g. MoRGAN et al., 2001; STEIGER et al., 2002), but found to be trait and environment dependent in others (e.g. GonZALES-MARTINEZ et al., 2002; PALO et al., 2003).

For neutral genetic markers, differentiation among populations typically, but not always, increases with geographic distance, as is the case for our data (correlation between geographic distance and $\mathrm{F}_{\mathrm{ST}}$ for Data-set 1: $r=0.64, P<0.001)$. In quantitative traits, patterns of differentiation are governed mainly by local selection pressures. Thus, one would expect a similar distance relationship if the heterogeneity in selection pressures is also a function of geographic distance. While this remains currently an untested hypothesis, it seems plausible that the correlation between $\mathrm{F}_{\mathrm{ST}}$ and $\mathrm{Q}_{\mathrm{ST}}$ estimates could be driven by different processes which bear a similar relationship to geographic distance separating pairs of populations.

\section{Marker vs. quantitative genetic diversity}

We found that the levels of intrapopulation genetic variability in neutral markers was unrelated to intrapopulation variability in quantitative traits, as measured by heritability and coefficient of additive genetic variance. This is in accordance with the few similar tests conducted so far (e.g. CHEverud et al., 1994; WALDMANN and ANDERSSON, 1998; LYNCH et al., 1999; Hurme et al., 2000; PFrENDER et al., 2000; but see: BRISCOE et al., 1992; ZHAN et al., 2005). This results is perhaps not surprising, given the multitude of factors that might influence levels of variability in quantitative traits (reviewed in PFRENDER et al., 2000). Furthermore, despite $C$. odorata having a very small genome (WILSON et al., 2001), the relatively few RAPD loci included in this study may not give a representative picture of genome-wide genetic variability. Hence, together with the limited number of populations surveyed, the results of our comparison may be viewed as conservative. However, given that our sample sizes were not smaller than those used in a typical conservation genetic study of wild populations, our results are in line with the conjecture that neutral genetic markers may not be very useful for purposes of inferring levels of variability in quantitative traits (LYNCH, 1996; PEARMAN, 2000; PFRENDER et al., 2000).

\section{Implications for management of endangered Spanish cedar populations}

Our analyses of neutral genetic markers and quantitative traits revealed strong differentiation among the Mesoamerican populations of C. odorata. For quantitative traits, these results are concordant with earlier reports of high differentiation within and among Costa Rican and Nicaraguan C. odorata populations (NAVARRO 
and VASQUEZ, 1987; NAVARRO et al., 2002). However, the much wider geographical range covered by the current study shows that these earlier studies capture only a limited proportion of the diversity exhibited by this wide-spread species. In particular, there appears to be clear ecotypic differentiation to two forms corresponding to populations inhabiting dry and mesic environments (Fig. 2 and 3). Hence, for quantitative traits, there exist at least two well-differentiated forms or ecotypes of C. odorata, each of which may be locally adapted to contrasting environmental conditions (see also GRAHAM, 1999). The practical implication of these results is that there is a need to maintain in-situ conservation areas, as well as ex-situ and circa-situ gene banks and plantations, for not only one, but at least for two forms of the endangered $C$. odorata. Naturally, the priority should be given to the areas where the species is most endangered.

Likewise, our analyses of RAPD differentiation concurred with results of GILLIES et al. (1997) and CAVERS et al. (2003), but covered a much wider geographic range. Given the socio-economic importance and endangered status of $C$. odorata, our results highlight the need for future studies encompassing the species' whole natural distribution including as yet unstudied populations in South America.

\section{Acknowledgements}

Our research was supported by CATIE (Tropical Agricultural Research and Higher Education Center), United States Department of Agriculture (USDA) (C.N.), and the Academy of Finland (J.M.). The financial support of the United States Department of Agriculture FAS Grant No. FG-CR-109 Project No. CS-FS-2 for the seed collection is gratefully acknowledged. Special acknowledgements are given to the EU project "Assessment of levels and dynamics of intra-specific genetic diversity of tropical trees" (contract \# ERBIC18CT970149 http://www.nbu.ac.uk/ inco) which was coordinated by A. LOwE.

We thank the following persons for their collaboration in seed collection, trial establishment, and data collection: Marvin Hernández, Gustavo Hernández, Luis Sánchez, Leonel Coto, Manuel Sojo, Kevyn Wightman, the members of the seed network of CATIE and the personnel of INIFAP Mexico l. We thank Simo HARJU and TertTU PARKKARI for the help with greenhouse work. and finally JONATHAN CORNELIUS and SHEILA WARD for the valuable advice and support.

\section{References}

Aguilar, M. and M. C. Aguilar (1992): Árboles de la Biosfera Maya Petén. Universidad de San Carlos de Guatemala, Guatemala. $272 \mathrm{p}$.

AvisE, J. C. (1994): Molecular markers, natural history, and evolution. Chapman and Hall, New York.

Avise, J. C. and J. L. HAMRICK (1996): Conservation genetics. Case histories from nature. Chapman and Hall, New York.

Briscoe, D. A., J. M. Malpica, A. Robertson, G. J. Simith, R. FRANKHAM, R. G. BANKS and J. S. F. BARKER (1992): Rapid loss of genetic variation in large captive population of Drosophila flies: implications for the genetic management of captive populations. Conservation Biology 6: 416-425.
Burley, J. and A. F. A. LAmb (1971): Status of the C.F.I. International provenance trial of Cedrela odorata (including C. mexicana and C. tubiflora). Commonwealth Forestry Review 50: 234-237.

Butlin, R. K. and T. TRegenza (1998): Levels of genetic polymorphism: marker loci versus quantitative traits. Proceedings of the Royal Society of London B. 358: 187-198.

Cavers, S., C. Navarro and A. J. Lowe (2003): A combination of molecular markers identifies evolutionarily significant units in Cedrela odorata L. (Meliaceae) in Costa Rica. Conservation Genetics 4: 571-580.

Cavers, S., C. NAVARRo and A. J. Lowe (2004): Targeting genetic resource conservation in widespread species: a case study of Cedrela odorata L. Forest Ecology and Management 197: 285-294.

Cheverud, J., E. Routman, C. Jaquish, S. Tardif, G. Peterson, N. Belfiore and L. Forman (1994): Quantitative and molecular genetic variability of captive cotton-top tamarins (Saguinus oedipus). Conservation Biology 8: 95-105.

Dawson, I., A. Simons, R. Waugh and W. Powell (1995): Diversity and genetic differentiation among subpopulations of Gliricida sepium revealed by PCR-based assays. Heredit. 74: 10-18.

EdMAns, S. and S. J. HARRISON (2002): Molecular and quantitative trait variation within and among populations of the intertidal copepod Tigriopus californicus. Evolution 57: 2277-2285.

Excoffier, L., P. E. Smouse and J. M. QuATtRo (1992): Analysis of molecular variance inferred from metric distances among DNA haplotypes: application to human mitochondrial DNA restriction data. Genetics 131: 479-491.

FrANKHAM, R. (1999): Quantitative genetics in conservation biology. Genetic Research 74: 237-244.

Dieters, M. J., T. L. White, R. C. Littell and G. R. HoDGE (1995): Application of approximate variances of variances components and their ratios in genetic tests. Theoretical and Applied Genetics 91: 15-24.

Gillies, A. C. M., J. P. Cornelius, A. C. Newton, C. Navarro, M. Hernández and J. Wilson (1997): Genetic variation in Costa Rican populations of the tropical timber species Cedrela odorata L. assessed using RAPDs. Molecular Ecology 6: 1133-1146.

Gillies, A. C. M., C. Navarro, A. J. Lowe, A. C. Newton, M. Hernandez, J. Wilson, J. P. Cornelius (1999): Genetic diversity in Mesoamerican populations of mahogany (Swietenia macrophylla), assessed using RAPDs. Heredity 83: 722-732.

Gonzalez-Martinez, S. C., R. Alia and L. Gill (2002): Population genetic structure in a Mediterranean pine (Pinus pinaster Ait.): a comparisopn of allozyme markers and quantitative traits. Heredity 89: 199-206.

CRNOKRAK, P. and J. MERILÄ (2005): Genetic population divergence: markers and traits. Trends in Ecology and Evolution 17: 501.

Graham, A. (1999): Studies in Neotropical paleobotany. XIII. An Oligo-Miocene palynoflora from Simojovel (Chiapas, Mexico). American Journal of Botany 86: 17-31.

HAIG, S. M. (1998): Molecular contributions to conservation. Ecology 79: 413-425.

HARDY, O. J., S. VANDERhoeven, P. Meerts and X. VeKeMANS (2000): Spatial autocorrelation of allozyme and quantitative markers within a natural population of Centaurea jacea (Asteraceae). Journal of Evolutionary Biology 13: 656-667. 
Hartl, D. L. and A. G. Clark (1989): Principles of population genetics. Sinauer, Sunderland, Mass.

Holsinger, K. E. and P. O. Lewis (2002): Hickory. http://darwin.eeb.uconn.edu/hickory/

Holsinger, K. E., P. O. Lewis and D. K. Dey (2002): A Bayesian approach to inferring population structure from dominant markers. Molecular Ecology 11: 1157-1164.

Houle, D. (1992): Comparing evolvability and variability of quantitative traits. Genetics 130: 195-204.

Hurme, P., M. J. Sillanpa, E. Aruas, R. TAPani and O. SAVolainen (2000): Genetic Basis of Climatic Adaptation in Scots Pine by Bayesian Quantitative Trait Locus Analysis. Genetics 156: 1309-1322.

InFoStat (2005): InfoStat versión p.1. Grupo InfoStat, FCA, Universidad Nacional de Córdoba, Argentina

Karhu, A., P. Hurme, M. Karjalainen, P. Karvonen and K. KARKKAINEN (1996): Do molecular markers reflect patterns of differentiation in adaptive traits of conifers? Theoretcial and Applied Genetics 93: 215-221.

KNAPP, E. E. and K. J. RICE (1998): Comparison of isozymes and quantitative traits for evaluating patterns of genetic variation in purple needlegrass (Nasella pulchra). Conservation Biology 12: 1031-1041.

LANDE, R. and G. F. BARROCLOUGH (1987): Effective population size, genetic variation, and their use in population management. Pp. 87-123. In: Viable populations for conservation (Soulé, M., ed.). Cambridge Univ. Press, Cambridge.

LeE, C. E. and B. W. Frost (2002): Morphological stasis in the Eurytemora affinis complex (Copepods: Temoridae). Hydrobiologia 480: 111-128.

LONG, A. D. and R. S. Singh (1995): Molecules versus morphology: the detection of selection acting on morphological characters along a cline in Drosophila melanogaster. Heredity 74: 569-589.

Lowe, A. J., J. Wilson, A. C. M. Gillies and I. Dawson (2000): Conservation genetics of bush mango from central/west Africa, implications from RAPD analysis. Molecular Ecology 9: 831-841.

LYNCH, M. (1996): A quantitative genetic perspective on Conservation issues. Pp. 471-501. In: Conservation Genetics: Case Histories from Nature (Avise, J. C. and HAMRICK, J.L., eds.). Chapman and Hall, New York.

Lynch, M., M. Pfrender, K. Spitze, N. Lehman, J. Hicks, D. Allen, L. Latta, M. Ottene, F. Bogue and J. ColBOURNE (1999): The quantitative and molecular genetic architecture of a subdivided species. Evolution 53: $100-110$

McKaY J. K., J. G. Bishop, J.-Z. Lin, J. H. RichaRdS, A. SAlA and T. Mitchell-OldS (2001): Local adaptation across a climatic gradient despite small effective population size in the rare sapphire rockress. Proceedings of the Royal Society of London B. 268: 1-7.

MCKAY, J. K. and R. G. LATTA (2002): Adaptive population divergence: markers, QTL and traits. Trends in Ecology and Evolution 17: 285-291.

MERILÄ, J. and P. CRNOKRAK (2001): Comparison of genetic differentiation at marker loci and quantitative traits. Journal of Evolutionary Biology 14: 892-903.

Morgan, K. K., J. Hicks, K. Spitze, L. Latta, M. E. Prefender, C. S. WeaWer, M. Ottone and M. Lynch (2001): Patterns of genetic architecture for life-history traits and molecular markers in a subdivided species. Evolution 55: 1753-1761.

MoRITZ, C., S. LAVERY and R. SLADE (1995): Using allele frequency and phylogeny to define units of conservation and management. American Fish Society Symposium. 17: 249-262.

NAVARRo, C. (1999): Annual year report of the Mesoamerican Domestication of Cedrela and Swietenia project. USDA. Grant No. FG-CR-109. Project No. CS-FS-2 USDA CATIE. Costa Rica, Turrialba. 20 p.

NAVARRO, C. and W. VÁZQUEZ (1987): Genetic variability in seeds and seedlings of Cedrela odorata. Paper presented at Congreso Forestal Nacional de Costa Rica, San Jose, Costa Rica, Nov. 1986; CAB Abstracts 1990-1991. Centro Agronomico Tropical de Investigacion y Ensenanza (CATIE). 12p.

NAVARRo, C., S. WARD and M. HeRnandeZ (2002): The tree Cedrela odorata (Meliaceae): a morphologically subdivided species in Costa Rica. Rev. Biol. Trop. 50: 21-29.

NeI, M. (1987): Molecular Evolutionary Genetics. Columbia University Press; $512 \mathrm{p}$.

Palo, J., R. O'Hara, A. T. Laugen, A. Laurila, C. P. PrimMER and J. MERILÄ (2003): Latitudinal divergence of common frog (Rana temporaria) life history traits by natural selection: evidence from a comparison of molecular and quantitative genetic data. Molecular Ecology 12: 1963-1978.

Pappinen, A., R. Kasanen and K. von Weissenberg (1996): Identification of multiple Endocronartium pini infections in Scots pine with PCR. European Journal of Forest Pathology 26: 183-191.

Pearman, P. B. (2001): Conservation value of independently evolving units: Sacred cow or testable hypothesis. Conservation Biology 15: 780-783.

Petit, C., H. Freville, A. Mignot, B. Colas, M. Riba, E. Imbert, S. Hurtrez-Bousses, M. Virevaire and I. OLIVIERI (2001): Gene flow and local adaptation in two endemic plant species. Biol. Cons. 100: 21-34.

Pfrender, M. E., K. Spitze, J. Hicks, K. Morgan, L. LATTA and M. LYNCH (2000): Lack of concordance between genetic diversity estimates at the molecular and quantitative-trait levels. Conservation Genetics 1: $263-269$

ReED, D. H. and R. Frankham (2001): How closely correlated are molecular and quantitative measures of genetic variation? A meta-analysis. Evolution 55: 1095-1103.

RoGers, A. R. (1986): Population differences in quantitative characters as opposed to gene frequencies. American Naturalist 127: 729-730.

Santamaría, L., J. Figuerola, J. J. Pilon, M. MJelde, A. J. Green, T. DE Boer, R. King, J. Gornall (2003): Plant performance across latitude: the role of plasticity and local adaptation in an aquatic plant. Ecology 84: $2454-2461$.

SpITZE, K. (1993): Population structure in Daphnia obtusa: quantitative genetic and allozyme variation. Genetics 135: 367-374.

Steinger, T., P. Haldiman, K. A. Leiss and H. MülleRSCHAÄRER (2002): Does natural selection promote population divergence? A comparative analysis of population structure using amplified fragment polymorphism markers and quantitative traits. Molecular Ecology 11: $2583-2590$

Squillace, A. E. (1974): Average genetic correlations among offspring from open pollinated forest trees. Silvae Genetica 23: 149-156.

Styles, B. T. (1981): Swietenioideae. Pp. 359-418. In: Meliaceae (T. D. Pennington, B. T. Styles and D. A. H. TAYLOR, Eds). Flora Neotropica Monographs, no. 28. New York Botanical Garden, New York. 
Templeton, A. (1986): Coadaptation and outbreeding depression. pp 105-116. In: Conservation Biology: the science of scarcity and diversity (M. Soulé ed.). Sinauer, Sunderland, MA.

WALDMANN, P. and S. ANDERsson (1998): Comparison of quantitative genetic variation and allozyme diversity within and between populations of Scabiosa canescens and $S$. columbaria. Heredity 81: 79-86.

WARD, R. D., D. O. F. SkIBINSKY and M. WoodmaRK (1992): Protein heterozygosity, protein structure and taxonomic differentiation. Evolutionary Biology 26: 3-131.

WHITLOCK, M. C. (1999): Neutral additive genetic variance in a metapopulation. Genetic Research 74: 215-221.

Wilson, J., A. J. Lowe, S. Cavers, C. Navarro, M. Hernandez, A. Kremer, H. Caron, P. Labbe, R. Margis,
M. Margis, P. Breyne, R. Gribel and M. Lemes (2001): Assessment of levels and dynamics of intra-specific genetic diversity of tropical trees. Final Scientific Report 1997-2001. European Commission. 76 pp.

WRIGHT, S. (1951): The genetical structure of populations. Annual Eugenics 15: 323-420.

YeH, F. C. and T. J. B. Boyle (1997): Population genetic analysis of co-dominant and dominant markers and quantitative traits. Belgian Journal of Botany 129: 157.

Zhan, J., C. C. Linde, T. Jürgens, U. Merz, F. SteineBRUNNER and B. A. MCDONALD (2005): Variation for neutral markers is correlated with variation for quantitative traits in the plant pathogenic fungus $M y c o s-$ pharella graminicola. Molecular Ecology 14: 2683-2693. 